\title{
Energiaital fogyasztási szokások és egészségtudatosság a felsőfokú képzésben résztvevő hallgatók körében
}

\author{
Energy drink consumption habits and health consciousness among \\ higher education students
}

\author{
Szerzők: Dojcsákné Kiss-Tóth Éva $₫$, Kiss-Tóth Emőke \\ a: Miskolci Egyetem, Egészségügyi Kar, Egészségfejlesztési Módszertani Intézet, \\ b: Miskolci Egyetem, Egészségügyi Kar, Alkalmazott Egészségtudományok Intézete
}

Beküldve: 2018. 05. 08.

doi: 10.24365/ef.v59i4.300

\begin{abstract}
Bevezetés: A fiatal felnőttek körében egyre divatosabbá váló energiaitalok fogyasztása számos, nem kívánt és nem ismert mellékhatással járhat együtt. A tanulmány elkészítésével az volt a célunk, hogy felmérjük a Miskolci Egyetem Egészségügyi Karán tanuló fiatal felnőttek energiaitalfogyasztási szokásait, azzal kapcsolatos tapasztalatait és egészségtudatosságát.

Módszertan: A kutatásunk alapjául szolgáló adatokat a Google dokumentumok ingyenes kérdőív készítő szoftverének a segítségével gyűjtöttük. A kérdőív a karon minden aktív státuszban lévő hallgató számára elérhető volt, kitöltése önkéntes alapon, anonim módon történt.

Eredmények: Az elvégzett felmérés szerint a hallgatók a serkentő hatású italokat leginkább tanulás, munka és társas összejövetelek során fogyasztják el a felfrissülés, a jobb koncentrálóképesség és a barátok kedvéért. Aggodalomra ad okot az a tény, hogy a fiatalok gyakran alkohol kíséretében fogyasztják az energiaitalt, aminek ritkán, nem várt egészségkárosító hatásai lehetnek.
\end{abstract}

Következtetés: Az eredmények alapján elmondható, hogy a hallgatók ismerik a mértéktelen energiaital-fogyasztás káros hatásait, ennek ellenére egy kis részük mégsem mond le kedvelt italáról.

Kulcsszavak: energiaital, egészségtudatosság, fiatal felnőttek, alkohol

Introduction: Energy drink consumption is becoming increasingly popular among young adults, which may involve many undesirable and unidentified side effects. The purpose of this study was to assess the energy drink consumption patterns, relating experiences and health consciousness of young adults studying at the Faculty of Health Care of the University of Miskolc.

Methodology: Data used in our research was collected by the free Google Docs questionnaire software. The questionnaire was accessible to all active students in the Faculty, and was filled in anonymously on a voluntary basis.

Results: According to the survey, stimulating beverages are consumed by students during learning, working and social gatherings as refreshment, to better concentrate, and for the sake of friends. The fact that young people often consume energy drinks accompanied by alcohol is a cause for concern, which may rarely have unexpected health-damaging effects.

Conclusion: Based on the results, it turns out that young people are familiar with the harmful effects of excessive energy drink consumption, even so, a small part of them do not give up drinking their favourite drink.

Keywords: energy drink, health consciousness, young adults, alcohol 


\section{BEVEZETÉS}

A fogyasztói piacon való megjelenésüktől számítva viszonylag rövid időn belül széles körben terjedtek el és váltak népszerúvé a serkentő hatású üdítők, az energiaitalok. Az első élénkítő italt feltehetőleg Skóciában állították elő 1901-ben, melyet magas vastartalmánál fogva Irn-Bru (Iron Brew) névvel illettek. Később, az 1920-as évek végén jelent meg a mintegy 60 évig forgalomban lévő Lucozade Energy nevű „gyógyital” Angliában, melyet kórházakban a betegek gyógyulásának elősegítésére, erősítőszerként alkalmaztak. ${ }^{1}$ Japánban 1960-ban a gyógyszertárakban, patikai üvegekben kezdték forgalmazni a Lipovan nevű terméket. ${ }^{1,2}$ 1985-ben Amerikában Jolt Cola néven került forgalomba az első magas koffeintartalmú készítmény. ${ }^{2}$

Ezzel párhuzamosan Európában 1987-ben jelent meg az üdítőital piacon a Red Bull, ami az emelt koffeintartalom mellett taurint és vitaminokat egyaránt tartalmazott. Hazánkban 1991-ben a termék egyedüli energiaitalként vált elérhetővé, míg 1997-ben került először az amerikai boltok polcaira, ahol gyorsan piacvezető energiaitallá vált. ${ }^{2}$ Ezt követően az energiaital-gyártás robbanásszerű ütemben indult fejlődésnek, világszerte százával láttak napvilágot újabb és újabb márkák, így 2006ra elérték az évi 5,7 milliárd dollár bevételt. ${ }^{3}$

2005-ben a Phusion Pharmaceuticals megkezdte a Four Loko, az első alkohol tartalmú energiaital forgalmazását. ${ }^{4}$

Az alkoholmentes, frissítő hatású italokkal kapcsolatban azt láthatjuk, hogy a népegészségügyi termékadó ellenére is leginkább a fiatalok körében terjedtek el robbanásszerüen és mára egyre szélesebb körben válnak mindennapi fogyasztási cikké a jó minőségű és ízvilágú italok. A fogyasztói sajátosságot felismerve, a gyártók évről-évre újabb ízcsaláddal lepik meg az újdonságot kereső, hagyományos ízvilágot kevésbé kedvelő (fiatal) fogyasztókat. A piacon elérhető termékek folyamatos fejlesztésének, a marketing fiatal fogyasztókhoz való igazításának és az évről-évre megújuló ízpalettának köszönhetően az energiaitalok kereskedelmi forgalma folyamatosan növekszik országvilágszerte. Ezt támasztják alá a Nielsen Piackutató Kft. eredményei is, amely szerint 2014. december és
2015. november között a sport- és energiaitalok piaci forgalma meghaladta a 20 milliárd forintot. ${ }^{5}$

Az energiaitalok a cukor, a B-vitamin és a színező anyagok mellett számos gyógynövény-kivonatot és koffeint is nagymértékben tartalmaznak. A hozzáadott, legdivatosabb természetes növényi alapú hatóanyagok a guarana és a ginzeng. A guarana a természetközeli népeknél régóta használt természetes stimuláló szer, magas koffein, teofillin és teobromin összetevőinél fogva. Az energiaitalokhoz adva a koffein mellett additív élettani hatással bír, erősíti annak felfokozó, serkentő jellegét. Jól ismert a keleti gyógyászatban a ginzeng, de teljesítményfokozóként elterjedt a sportolók körében is. Fő komponensként jelenik meg az energiaitalokban a taurin is, amely az emberi szervezetben természetesen is jelen lévő kéntartalmú aminosav. Legnagyobb mennyiségben az agyban fordul elő, de emellett számos egyéb élettani folyamatban is fontos szerepet játszik. Míg az emberi szervezet számára $60 \mathrm{mg}$ taurin elegendő, addig az energiaitalok gyakran 1000 mg-ot is tartalmaznak, aminek az elfogyasztása esetén hasmenéssel, rövid távú memóriavesztéssel, elvonási tünetekkel, depresszióval kell számolnunk. ${ }^{3}$

Az energiaitalok élettani szempontból legjelentősebb alkotóeleme a koffein. A metilxantin vegyületcsaládhoz tartozik, pszichoaktív hatását adenozin receptor agonista tulajdonságán keresztül érvényesíti. Alapvetően az egészséges emberi szervezetnek nincs szüksége koffeinre. Az ételekkel és italokkal elfogyasztott koffein egyénenként változó időtartammal és erősséggel fejti ki anyagcsere-fokozó hatását. A gyors felszívódást követően a koffein felezési ideje 2,5 és 10 óra között változik. ${ }^{3} A$ vérben mérhető legmagasabb koffein koncentráció a fogyasztást követő 15-120 perc elteltével jelenik meg, ezzel egy időben gyorsítja az anyagcserét, ezáltal emeli a szervezet hőtermelését és serkenti a vizelet kiválasztást. Fokozza az izmok teljesítő képességét, a szív- és az idegrendszer múködését, valamint javítja a szellemi képességeket (koncentráció, döntéshozatal). ${ }^{6}$ Figyelnünk kell azonban arra, hogy egészséges felnőttek az Európai Élelmiszerbiztonsági Hatóság (Europen Food Safety Authority) által ajánlott napi 400 mg koffein mennyiséget ne haladják túl. Terhes és szoptató nők esetében ezt a mennyiséget 200 mg-ban, 
míg gyermekek esetében 3 mg/testtömeg kilogrammban korlátozták. ${ }^{7}$

A legtöbb energiaital 100 ml-ben 30-32 mg koffeint és 400 mg taurint tartalmaz. ${ }^{8}$ Az utóbbi években pedig megjelentek a nagy kiszerelésű, ám kedvezőbb árfekvésű ( $600 \mathrm{ml}, 1500 \mathrm{ml}$ ) termékek is a boltok polcain. Ezeknek egyenes következménye az a tény, hogy az energiaitalokat előszeretettel fogyasztó fiatal (15-29 év közötti) korosztály - akik a koffeinre nézve egyébként is érzékenyebbek könnyen túladagolhatják a serkentő hatású italokat, valamint magát a koffeint.

A koffeintúladagolás következményeként ezek a fogyasztók gyakran számolnak be kellemetlen mellékhatásokról, mint a hányinger és a hányás, gyomorpanaszok, szívritmus problémák, de súlyos esetben életet veszélyeztető mellékhatásokkal (infarktus, máj- és vesekárosodás) is számolni lehet, ami orvosi ellátást igényelhet. Ezt támasztja alá egy 2016-ban megjelent tanulmány is, miszerint az energiaital- fogyasztás megváltoztatja a vérlemezkék és az érfalat borító endothel sejtek funkcióját, ami szívizom infarktus kialakulásához vezethet. ${ }^{9}$

Az Állami Népegészségügyi és Tisztiorvosi Szolgálat (ÁNTSZ) által 2012. január 17. és február 27. között elvégzett anonim kutatás két fontos tényre hívta fel a figyelmet a fiatalkorúak energiaitalfogyasztási szokásaival kapcsolatban. A felmérés szerint a 10-18 éves korosztály $86 \%$-a fogyasztott már energiaitalt, és annak ellenére, hogy ismerik és tapasztalták is azok mellékhatásait, 63\%-uk tartja magát rendszeres fogyasztónak. A függőség már ebben a korosztályban kialakul a serkentő hatású italokat rendszeresen fogyasztók körében. A másik aggasztó eredmény arra mutat rá, hogy a gyermekek 10\%-a már 6-8 éves korban megismerkedik ezekkel az élvezeti cikkekkel. ${ }^{3,10}$

A fiatal felnőtt (18-29 év közötti) korosztály esetében a fenti hatásokon túl további veszélyt jelent az energiaitalok és egyéb szerek együttes fogyasztása. A korábbi tanulmányok eredményei alapján elmondhatjuk, hogy ez a korosztály leginkább a tanulás és a munka során fogyaszt energiaitalokat a jobb koncentrálóképesség elérésének érdekében. Azonban a megkérdezettek közel fele fogyasztási szokása okaként a szórakozást jelölte meg. ${ }^{11}$
A szórakozások, bulik alkalmával a fiatalok gyakran fogyasztják alkohol kíséretében az energiaitalokat, annak ellenére, hogy az üdítők dobozán a gyártó feltünteti ennek veszélyeit.

Számos külföldi szakirodalom szerint az utóbbi évek során drámaian megemelkedett a fiatalok körében az alkohol és az energiaital együttes fogyasztása. ${ }^{12}$ Ezt összefüggésbe hozzák a kockázatos ivási magatartásokkal, gyakoribb baleseti és sérüléssel járó esetekkel. Közismert tény, hogy az alkoholfogyasztás önmagában csökkenti a gátló és aktiváló mechanizmusok ellenőrzését, valamint megnöveli a válaszidőt. ${ }^{13}$ Egy másik tanulmány szerint az alkohol önmagában lassította a párhuzamos feladatmegoldásból származó információk feldolgozását és csökkentette az egyszerü és összetett mozgások koordinációját. ${ }^{14}$ Közegészségügyi szempontból az alkohol energiaitallal egy időben fogyasztva veszélyesebb, mint önmagában. Különösen olyan kockáztató magatartások esetén, mint a tivornyázás, kockázatos szexuális viselkedés, valamint ittas gépjármú vezetés során, csökkent vezetői képességek mellett. Együttes fogyasztásuk megváltozott szubjektív állapotokhoz vezet, beleértve a felfokozottságot, az intoxikációs állapot érzetének a csökkenését, és az ivás iránti vágy növekedését. Úgy tûnik, hogy az energiaitallal kevert alkoholfogyasztás sokkal jutalmazóbb az agy bizonyos területeire nézve, mint a szimpla alkoholfogyasztás, így az energiaital alkohollal egyidejúleg fogyasztva nagyobb motivációt eredményezhet a további alkoholfogyasztásra. ${ }^{15,16}$

Összességében elmondható, hogy a kevert italfogyasztás során az energiaital tompítja az alkohol hatását, mert átmenetileg serkent, fokozza a teljesítményt, emiatt a fiatalok nem veszik észre milyen sok alkoholt fogyasztottak. Lényegében egy időben érvényesül a serkentő és a gátló hatás, azonban a koffein hamarabb felszívódik, mint az alkohol. Amikor az energiaital serkentő hatása megszűnik, az alkoholnak egyszer csak löketszerúen jelentkezik a deprimáló hatása. Ezek miatt az energiaital és az alkohol együttes fogyasztása végleges károsodást okozhat a májban, a szívben és a vesében is. Schöffl és munkatársai akut veseelégtelenség kialakulásával hozták kapcsolatba a nagy mennyiségú alkohol és a taurinnal kapcsolt koffein fogyasztásának hatását. ${ }^{17}$ 
2015-ben jelent meg egy hazai tanulmány, egy esetismertetés, amely erre a jelenségre szerette volna felhívni a figyelmet. Egy budapesti kórház két kardiológus orvosa írta le annak a 22 éves fiatal férfinak az esetét, akinél alkohollal elfogyasztott nagy dózisú energiaital hatására életet veszélyeztető kardiológiai jelenség következett be. A szerzők az eset kapcsán arra hívták fel a figyelmet, hogy az energiaital a nagy mennyiségú koffein tartalma miatt az EKG-n is látható QT-szakasz megnyúlást eredményezett, amely végső soron akár malignus szívritmuszavart (polimorf kamrai tachicardiát), és hirtelen szívmegállást okozhat. A nagy dózisú energiaital (koffein) alkohollal együttesen fogyasztva, illetve fizikai terheléssel párosulva kiemelten veszélyes lehet olyan személyek esetében, akik manifeszt vagy akár néma hosszú QT szindrómával élnek. ${ }^{18}$

Kanadában 2003 és 2012 között 35 olyan fiatalt regisztráltak, akiknél komoly egészségkárosodást okozott, 3 esetben pedig halálos kimenetele volt az energiaital-fogyasztásnak. ${ }^{19}$ Ezért a Health Canada 2010-ben "stimuláns drogokat tartalmazó italnak” jelölte az energiaitalokat és javaslatokat tett az energiaitalfogyasztási határértékekre a különböző korosztályok számára. Az Amerikai Egyesült Államokban 2007 és 2011 között megduplázódott az energiaitalok miatt szükségessé vált sürgősségi ellátások száma. Az Amerikai Élelmiszer- és Gyógyszerügyi Hivatal (U.S. Food and Drug Administration) 2004 és 2012 között 30 halálesetet hozott összefüggésbe az energiaitalok fogyasztásával. Ausztráliában a toxikológiai központba érkezett kardiológiai esetekkel, hallucinációkkal és rosszullétekkel kapcsolatos jelentések száma ötszörösére emelkedett 2004 és 2010 között. ${ }^{19}$

Hazánkban 2011. november és 2015. szeptember között az Országos Tisztifőorvosi Hivatal 379 energiaital-fogyasztással összefüggésbe hozható rosszullétet, megbetegedést regisztrált. ${ }^{20}$

Annak ellenére, hogy korábban néhány európai országban (Dánia, Franciaország) teljesen betiltották az energiaitalok forgalmazását, ma már kontinensszerte elérhetők a fogyasztók számára. ${ }^{21}$ Több nemzeti ajánlás is létezik, amelyek elsősorban a koffein- és taurintartalom csökkentését célozzák, emellett láthatunk példákat arra is, hogy Litvánia,
Írország, az Egyesült Királyság és Svédország tiltja a fiatalkorúak számára történő forgalmazását. Az alkoholtartalmú energiaitalok forgalmazását az Egyesült Államok több államában és egyetemén is betiltották, Hollandiában pedig külön állásfoglalást adtak ki ezekre az italokra. ${ }^{21,22} \mathrm{Az}$ Európai Unió - a felmérései alapján tapasztalt probléma megoldása érdekében - fontolgatja az energiaitalok fogyasztásának szabályozását, elsősorban a fiatalkorúak körében.

Hazánkban energiaital-fogyasztással kapcsolatos, hatályos jogszabály jelenleg nincs érvényben. A kinint és koffeint tartalmazó élelmiszerek címkézéséről szóló 2002/67/EK irányelv szerint a gyártó köteles feltüntetni a „magas koffein tartalmú" feliratot a terméken, amennyiben annak koffeintartalma meghaladja a $150 \mathrm{mg} / \mathrm{ml}$ mennyiséget. Emellett 2011-ben a népegészségügyi termékadó (NETA) bevezetésével (2011. évi CIII. törvény a népegészségügyi termékadóról) energiaitalként definiálták azokat a termékeket, melynek metil-xantin tartalma meghaladja a 15 milligramm metil-xantin/100 milliliter mennyiséget vagy taurin tartalma meghaladja a 100 milligramm taurin/100 milliliter mennyiséget, és adóval sújtották ezeket. ${ }^{23} \mathrm{~A}$ nevelési-oktatási intézmények múködéséről és a köznevelési intézmények névhasználatáról szóló 20/2012 (VIII.31.) EMMI rendelet pedig kimondja, hogy a NETA szabályozása alá eső termékeket oktatási-nevelési intézményekben nem forgalmazhatják. A magyarországi törvényhozás elfogadta az „Egészséges Magyarország 2014-2020" Egészségügyi Ágazati Stratégiát (1039/2015. (II. 10.) Kormányhatározat); a jövőben a Stratégia Táplálkozás-egészségügyi Szakpolitikai Programjában tervezik a kereskedelmi forgalomban kapható energiaitalok térfogategységét maximálni és ellenőrizni.

A tanulmány elkészítésével az volt a célunk, hogy megvizsgáljuk az egészségügyi tanulmányokat folytató hallgatók energiaital- fogyasztási szokásait, egészségtudatosságát, és felhívjuk a divatos frissítőket leginkább fogyasztó fiatal felnőttek figyelmét az energiaital alkohollal történő együttes fogyasztásának komoly veszélyeire. 


\section{MÓDSZERTAN}

A kérdőív elkészítését megelőzően áttekintettük az utóbbi öt év hazai és nemzetközi energiaital témakörben publikált szakirodalmát, különös tekintettel a fogyasztással kapcsolatos veszélyekre. Emellett hangsúlyt fektettünk a témában korábban napvilágot látott, hazai és nemzetközi felmérések eredményeinek a megismerésére saját kutatásunk megalapozásához.

A kérdőív elkészítésekor részben alkalmaztunk már korábban közölt felmérésben is szereplő elemeket ${ }^{11}$, ugyanakkor kibővítettük olyan saját szerkesztésű kérdésekkel, amelyeknek a segítségével hallgatóink egészségattitűdjére és egyéb élvezeti szerek egyidejű használatára vonatkozó információkat kaptunk.

Mintavételi csoportunknak a Miskolci Egyetem Egészségügyi Karán nappali tagozaton alap- és levelező képzésben résztvevő hallgatókat tekintettük, mindkét nem esetében.

A kérdőív négy szakaszra tagolódott, összesen 35 zárt kérdést tartalmazott, melynek kitöltése néhány percet vett igénybe. A kérdőívvel kapcsolatos tudnivalók ismertetését követően 3 szociodemográfiai és tanulmányi adatokra vonatkozó információra kérdeztünk rá. Ezt követően 19 energiaitalfogyasztási szokásokra (első fogyasztás, elvárások az energiaital-fogyasztás során, fogyasztási gyakoriság, tapasztalt mellékhatások) és attitúdre (energiaitallal kapcsolatos ismeretek, ezek figyelembevétele a fogyasztás során, egyéb élvezeti szerekkel történő egyidejű fogyasztás) vonatkozó, valamint 13 kávéfogyasztási szokás iránt érdeklődő kérdést tettünk fel. Az utóbbiból származó adatokat ebben a dolgozatban nem értékeltük.

A kutatásunk alapjául szolgáló adatokat a Google dokumentumok ingyenes kérdőív készítő szoftverének (https://docs.google.com/forms/d/1th7LhkefRIRcjVotSUaoYywwe5b18VYy6CvI6Ci-pro/edit) a segítségével gyúitöttük 2017. október 3. és 2017. december 3. között.

A kérdőív nyilvánosan elérhető linkjét (https://docs.google.com/forms/d/e/1FAlpQLSepCTOP6gWDIJ3hdnbGRHJ8z3BQVSd2joxGDgiAE9 Fs3RB_mQ/viewform?usp=sf_link) a Miskolci Egyetem Egészségügyi Karán minden aktív státuszban lévő hallgatónak eljuttattuk az egyetem elektronikus tanulmányi rendszerén, majd a kar hivatalos Facebook oldalán keresztül (https://www.facebook.com/meek2001/). A kérdőív kitöltése önkéntes alapon, anonim módon történt.

A gyermekek védelméről és a gyámügyi igazgatásról szóló 1997. évi XXXI. törvény 5. paragrafusa szerint fiatal felnőtt az a nagykorú személy, aki a 24. évét nem töltötte be, ezért tanulmányunk kiértékelésekor csak azoknak a hallgatóknak a válaszát használtuk fel, akik a fenti kritériumnak megfeleltek.

Az adatok elemzésekor kizártuk a kiértékelésből a hiányos demográfiai adatokat tartalmazó, illetve a megkezdett, de végig ki nem töltött kérdőíveket, valamint a 24. életévet betöltött hallgatók válaszait.

A kar hallgatói létszámából és a kitöltési hajlandóságból adódóan eredményeink nem alkalmasak kiterjedt statisztikai vizsgálatok elvégzésére.

\section{EREDMÉNYEK}

\section{A minta jellemzői}

Két hónap alatt 230 hallgató töltötte ki az „Energiaital- és kávéfogyasztási szokások az egyetemisták körében" című kérdőívet, ami a kar aktív státuszban lévő 792 hallgatójának 29,0\%-a. A válaszok elemzése során a módszertani részben leírt ismérveket alapul véve 193 kitöltött kérdőívet tudtunk felhasználni a végleges analízishez.

A válaszadók 91,2\%-a (176 fő, átlagéletkora 20,9 $\pm 1,6$ év) nő volt, és 8,8\%-a (17 fö, átlagéletkora 20,8 $\pm 1,6$ év) férfi. A kitöltők kisebb aránya, 42,7\%-a rendelkezett egészségügyi előképzettséggel, ami esetünkben egészségügyi szakközépiskolai végzettséget, illetve emelt szintű biológia érettségit jelentett.

\section{Energiaitalfogyasztási szokások}

A megkérdezettek döntő többsége, 95,3\%-a kipróbálta már az energiaitalt, és az első ilyen serkentő hatású italát (64,9\%) barátok körében, felnőtt családtag jelenlétében (16,2\%) vagy egyedül $(10,8 \%)$ fogyasztotta el. A családi energiaitalfogyasztást vizsgáló kérdésben kiderült, hogy a 
hallgatók 37,4\%-ának a családjában más nem fogyasztja ezt az élénkítő szert, míg leggyakrabban a testvér $(35,3 \%)$ vagy a párja $(32,1 \%)$ iszik ilyen italból.

A fiatalok energiaitallal szemben támasztott elvárásai között első helyen szerepel a fáradtság érzésének leküzdése (54,8\%), illetve az energikusság $(37,1 \%)$, a felfrissülés, élénkítő hatás $(34,4 \%)$ elérése, hiszen legtöbben a tanulás során (52,3\%) és a munkavégzés alkalmával (20\%) fogyasztják az energiaitalt, amikor fontos számukra a jobb koncentráló- és teljesítőképesség. Az ital fogyasztásától a megkérdezettek 25,3\%-a várja a felpörgetettség, 22,6\%-a teljesítmény fokozását, ami indokolttá teszi a társas összejövetelek alkalmával $(32,9 \%)$ vagy a sportolás során $(1,9 \%)$ történő energiaital-fogyasztást.

\section{Mennyiség és hozzászokás}

Az első kipróbálást követően a válaszadók 31,7\%-a egy héten belül, 20,4\%-a egy hónapon belül újra fogyasztotta a koffeintartalmú italt. Mindössze 10,8\% vallotta azt, hogy soha többé nem ivott újra energiaitalokat. A fogyasztási gyakorisággal kapcsolatos kérdésre a fiatalok 3,7\%-a és 3,2\%-a válaszolta azt, hogy naponta több vagy egy alkalommal fogyasztja az italt. A válaszadók 14,4\%-a hetente több alkalommal, 15,5\%-a havonta, 24,1\%-a pedig ritkábban iszik energiaitalt.

A magas koffeintartalmú italok fogyasztása során a fiatalok gyakran nem veszik figyelembe az összetevők mennyiségét, és hajlamosak akár többet fogyasztani a javasoltnál. A megkérdezettek $89 \%$-a vallotta azt, hogy naponta/alkalmanként $2 \mathrm{dl}$-t iszik ezekből az üdítőkből, 11\%-uk esetében az egy alkalommal elfogyasztott mennyiség $5 \mathrm{dl}$ volt.

Kíváncsiak voltunk arra, hogy ennek a divatos üdítő féleségnek a fogyasztása mennyire vált hallgatóink életének a részévé. 94,1\% el tudta képzelni egy napját energiaital-fogyasztás nélkül, $4,8 \%$ válaszolta azt, hogy talán, és $1,1 \%$ nem tudna lemondani róla.

\section{Más élvezeti cikkekkel egy időben történő energiaital-fogyasztás}

A hallgatók önbevallása szerint 6,5\%-uk fogyaszt energiaitallal egyidejúleg egyéb koffeintartalmú italt és 43,8\%-uk alkoholt.

A válaszadók véleményére is kíváncsiak voltunk, megkérdeztük, hogy szerintük a kortársaik milyen egyéb szerekkel fogyasztják egyidejűleg az energiaitalokat. Becsléseik szerint 90,3\%-ban alkohollal, 25,9\%-ban egyéb koffeintartalmú italokkal isszák egyidejűleg a népszerű serkentőket.

1. táblázat: Az energiaitalt fogyasztó fiatal felnőttek körében tapasztalt mellékhatások

\begin{tabular}{|c|c|}
\hline \multirow[b]{2}{*}{ Tapasztalt mellékhatás } & Válaszadók \%* \\
\hline & $\begin{array}{l}\text { A kérdésre választ adó fogyasztók száma } \\
\qquad(\mathrm{n}=177)\end{array}$ \\
\hline Nem tapasztalt mellékhatást & 50,3 \\
\hline Szédülés & 4,0 \\
\hline Gyengeség érzése & 2,3 \\
\hline Kézremegés & 9,0 \\
\hline Félelemérzet & 4,0 \\
\hline Idegesség érzet & 8,5 \\
\hline Álmatlanság & 7,3 \\
\hline Fejfájás & 7,3 \\
\hline Ájulás & 0,0 \\
\hline Magas vérnyomás & 9,6 \\
\hline Heves szívdobogás érzet & 29,9 \\
\hline Hányinger/hányás & 5,6 \\
\hline Gyomorbántalmak & 10,7 \\
\hline
\end{tabular}

Forrás: saját szerkesztés 


\section{Tapasztalt mellékhatások}

A kérdőívet kitöltők fele (50,3\%) nem tapasztalt még mellékhatást energiaital-fogyasztást követően. Önbevallás szerint a leggyakrabban megjelölt mellékhatások a kardiovaszkuláris rendszert és a gyomor-bélrendszert érintő kellemetlen tünetek voltak. Emellett néhányan idegrendszeri tüneteket is észleltek. [1. táblázat] Ennek ellenére a mellékhatásokat érzékelók 50,9\%-a mondta azt, hogy rosszulléte sem tartotta vissza a további energiaitalfogyasztástól.

\section{Egészségtudatosság}

Az energiaitalok túlzott fogyasztásából adódó veszélyekkel a válaszadók 74,7\%-a tisztában van, és 17,7\%-a vallotta azt, hogy emiatt nem fogyasztja az üdítőt. Mindössze 4,3\% állította azt, hogy nem ismeri a túlzott fogyasztás káros következményeit. A válaszokból az is kiderült, hogy a vásárlók $58,1 \%$-a szokta elolvasni az energiaitalok dobozán feltüntetett figyelmeztetéseket. A hallgatók 44,0\%-ának az energiaitalfogyasztási szokásait befolyásolja a veszély ismerete, azonban 29,1\%-uk vallja azt, hogy még így sem biztos abban, hogy lemondana kedvenc serkentő hatású italáról.

A fogyasztók nagy többsége $(81,5 \%)$ tisztában van azzal a ténnyel, hogy az energiaitalok nem alkalmasak a szomjúság enyhítésére és egyetértenek a kijelentéssel, hogy ezeknek az italoknak a nagymértékű (a válaszadók 70,4\%-a) vagy akár a kismértékú (a válaszadók 28,5\%-a) elfogyasztása is káros lehet az emberi szervezetre.

\section{MEGBESZÉLÉS}

Felmérésünkben a Miskolci Egyetem Egészségügyi Karán tanuló fiatal felnőtteket szólítottuk meg, azonban a mintacsoport kérdőívkitöltési hajlandósága alacsonynak (29\%) bizonyult. Emellett a kitöltők zömében a hölgyek köréből kerültek ki, a férfiak alulreprezentáltak. Ez az egyenlőtlen nemi arány nem meglepő, ha a kar alapképzési szakirányán tanulók nemi megoszlását vesszük alapul.

A felmérés során a megkérdezett fiatal felnőttek energiaitalfogyasztási szokásaiknak a hátterében általában nem a szülői minta, inkább a barátok és a kortársak szerepe a meghatározó. A serkentő hatású italokat leginkább tanulás, munka, sport, és szórakozások alkalmával fogyasztják el a felfrissülés, a jobb koncentráló- és teljesítóképesség, valamint a barátok kedvéért.

A Debreceni Egyetem Mentálhigiénés és Esélyegyenlőség Központja által 2010-ben elvégzett felméréssel hasonlóságot mutat a kapott eredmény, vagyis a fiatal felnőttek energiaitalfogyasztásában inkább a testvér, a kortárs, a barát és a baráti társas tevékenységek a meghatározók, így a szülői minta szerepe nem számottevő. ${ }^{11}$

A megkérdezettek nagy többsége nem haladja meg az ajánlott napi bevitelt ezekból az italokból, de akadnak olyanok is, akik akár fél litert is elfogyasztanak naponta, és nem tudnának lemondani kedvelt márkájukról. A válaszadók 3,7\%-a fogyaszt naponta több alkalommal energiaitalt és 1,1\%-a vallotta azt, hogy nem tudja elképzelni a napját kedvenc itala nélkül. A hallgatók 50,9\%-a vallotta az, hogy a korábban tapasztalt rosszulléte sem tartotta vissza a további energiaital-fogyasztástól, ami hozzászokásra utalhat.

Az önbevallások alapján az energiaitalokkal leggyakrabban egyidejúleg elfogyasztott szerek között az alkohol, valamint az egyéb, koffeintartalmú italok (kávé, tea, kakaó) szerepeltek a legnagyobb arányban, ami magában hordozza a koffeintúladagolás, illetve az alkoholtúlfogyasztás veszélyét. Eredményeink jól korrelálnak az Oteri és munkatársai által 2007-ben közölt adatokkal. A Messinai Egyetem orvostanhallgatóinak a körében végzett, kiterjedt tanulmányukban arról számoltak be, hogy az egyetemisták 48,4\%-a fogyasztja gyakran az energiaitalát alkoholos italok kíséretében. ${ }^{24}$ Eredményeinket megerősíti az a 2008-ban készült felmérés is, amelyben az energiaital-fogyasztás indoklásakor a testnevelési felsőfokú képzésben résztvevő hallgatóknak több mint a fele az alkoholos ital ízének a javítására hivatkozott. ${ }^{25}$

A hallgatók véleménye szerint a kortársaik fóként alkohollal és koffeintartalmú italokkal fogyasztják egyidejűleg az energiaitalokat. Érdekes adat azonban, hogy míg az önbevallásban a könnyú drogok csak 1,1 \%-ban jelentek meg, addig a társaik 
vélt szokásai kapcsán a könnyű droggal egy időben történő energiaital-fogyasztás nagyobb hangsúlyt kapott $(13,5 \%)$ és mellette megjelent a gyógyszerekkel történő együtt fogyasztás is $(15,7 \%)$, amely az önbevallásban egyáltalán nem szerepelt.

Végül kíváncsiak voltunk arra is, hogy az egészségügyi képzésben résztvevő fiatalok mennyire vannak tisztában az energiaital-fogyasztás lehetséges veszélyeivel és hogyan befolyásolja fogyasztási szokásaikat a már korábban megszerzett tudásuk, egészségügyi előképzettségük. A hallgatók közül sokan azt vallották, hogy ismerik a magas koffeintartalmú italok fogyasztásának a veszélyeit, már kis mértékben is károsnak ítélik meg az emberi szervezetre nézve. Azonban vannak, akik nem törődnek ezekkel a tényekkel és továbbra is isszák kedvelt üdítőjüket, sokszor a javasoltnál nagyobb mennyiségben, illetve egyéb élvezeti szerekkel kombinálva.

A vizsgálatunk limitációját alapvetően az online kérdőívekre jellemző, nem befolyásolható alacsony visszaérkezési arány képezi, továbbá nem zárható ki a kitöltések során mások véleményének a kikérése sem. Figyelembe kell vennünk azt a tényt is, hogy a kitöltésben részt nem vevő hallgatók eredményeinek a hiányában a kapott információk torzíthatnak, emellett felmerül annak a lehetősége, hogy a megkérdezettek nem minden esetben vallják be a fogyasztást.

Az alacsony kitöltési hajlandóságot, a vizsgálat limitációit, valamint az egészségügyi előképzettséget figyelembe véve azt mondhatjuk, hogy a vizsgálat eredményei nem tekinthetők reprezentatívnak sem az ország teljes fiatal felnőtt, sem felsőfokú képzési formáiban résztvevő lakosságára vagy a kar hallgatóira nézve. Célszerű a kapott adatokat rétegfelvételnek tekinteni, amelynek főbb vonulatai rámutatnak a fiatalok körében elterjedt energiaitalfogyasztási trendekre és az azok hátterében meghúzódó veszélyekre.

\section{KÖVETKEZTETÉSEK}

A fiatalkorúak energiaital-fogyasztása hazai és nemzetközi viszonylatban is egyre nagyobb mértéket ölt. A serkentő hatású ital jelen van a mindennapjaikban. Az Egészségügyi Kar vizsgálatunkban résztvevő hallgatóinak többségéről elmondható, hogy ismerik a túlzott koffeinbevitel káros hatásait, ennek ellenére mégsem tartják be minden esetben a mértéket, néhányan pedig a már kialakult függőséget sem tudatosítják magukban. További aggodalomra ad okot az a tény, hogy a fiatalok gyakran alkohol kíséretében fogyasztják a serkentő hatású italt összejövetelek, szórakozás során. A szakemberek ezeket a jelenségeket valós problémának tekintik, így több ország egyre drasztikusabban korlátozza az energiaital hozzáférhetőséget a korosztály tagjai számára, hazánkban azonban jelenleg nincs még rá jogszabályi háttér.

Annak ellenére, hogy ritkán tapasztalhatunk az energiaital-fogyasztásból adódó súlyos egészségi problémákat, egyre nagyobb a sürgetés mind az egészségügyi szakemberek, mind pedig a felelős hozzátartozók részéről egy olyan jogszabály megalkotására, amely felhívná a figyelmet a túlzott energiaital-fogyasztás veszélyeire és korlátozná azok hozzáférhetőségét a fiatalabb korosztály körében.

\section{KÖSZÖNETNYILVÁNITTÁS}

Köszönetünket fejezzük ki az Egészségügyi Kar hallgatóinak, akik a kérdőív önkéntes kitöltésével hozzájárultak a tanulmány megvalósulásához. A tanulmányban ismertetett kutató munka az EFOP3.6.1-16-00011 jelű „Fiatalodó és Megújuló Egyetem - Innovatív Tudásváros - a Miskolci Egyetem intelligens szakosodást szolgáló intézményi fejlesztése" projekt részeként - a Széchenyi 2020 Fejlesztési Program keretében - az Európai Unió támogatásával, az Európai Szociális Alap társfinanszírozásával valósul meg. 


\section{HIVATKOZÁSOK}

\footnotetext{
${ }^{1}$ Grósz A, Szatmári Á. Az energiaitalok története és hatása az emberi szervezetre. Orv. Hetil. 2008; 149 (47): 2237 2244. DOI: 10.1556/OH.2008.28491

2 Orgovány A. Huszonévesek energiaital-fogyasztási szokásai. In: A fogyasztás kérdései. Szolnoki Főiskola, Szolnok, 2013.

${ }^{3}$ Szőnyi L, Kiss E. Az energiaitalok hatása serdülőkorúakra. Gyermekorvos Továbbképzés, 2012; 11 (5): $197-202$.

${ }^{4}$ Mazur M. The History of Energy Drinks. https://www.preceden.com/timelines/66113-the-history-of-energy-drinks (Elérve: 2018.03.02.)

${ }^{5}$ Magyar Nemzeti Kereskedelmi Szövetség. http://www.mnksz.hu/hirek/jol-teljesit-az-energiaitalok-piaca (Elérve:2018.03.02)

6 „Koffein-függő” kérdések: Meddig használ és mikor sok? Táplálkozás és tudomány, 2007; 8(5): 1-6. http://mdosz.hu/hun/wp-content/uploads/2016/03/2007_05_tt.pdf (Elérve: 2018.02.15.)

${ }^{7}$ Nemzeti Fogyasztóvédelmi Hatóság. Az energiaitalok és kávék összehasonlító vizsgálatáról. Sajtóközlemény. http://fogyasztovedelem.kormany.hu/node/11030 (Elérve: 2018.03.02.)

8 Zucconi S., Volpato C., Adinolfi F., et al. Gathering consumption data on specific consumer groups of energy drinks. Supporting Publications 2013:EN-394. [190 pp.]. Available online: https://www.efsa.europa.eu/en/supporting/pub/en394 (Elérve: 2018.09.06.)

${ }^{9}$ Worthley MI., Prabhu A., De Sciscio P., et al. Detrimental Effects of Energy Drink Consumption on Platelet and Endothelial Function. Am J Med. 2010; 123(2):184-7. doi: 10.1016/j.amjmed.2009.09.013.

10 Állami Népegészségügyi és Tisztiorvosi Szolgálat. Kérdőív az energiaitalokról 10-18 évesek számára. https://www.antsz.hu/content/htmlform?contentid=231824 (Elérve: 2018.02.21.)

${ }^{11}$ Berényi A., Farkas É., Strausz K. A Debreceni Egyetem hallgatóinak energiaital fogyasztási szokásai. Debreceni Egyetem Mentálhigiénés és Esélyegyenlőségi Központ, Tanulmány, Debrecen, 2011. http://old.lelkiero.unideb.hu/sites/default/files/energiakut_tanulmany.pdf (Elérve: 2018.04.17.)

12 Marczinski C.A., Fillmore M.T., Bardgett M.E. et al. Effects of energy drinks mixed with alcohol on behavioral control: Risks for college students consuming trendy cocktails. Alcohol Clin Exp Res. 2011; 35(7): 1282-1292. doi:10.1111/j.1530-0277.2011.01464.x.

${ }^{13}$ Marczinski C.A. Combined Alcohol and Energy Drink Use: Hedonistic Motives, Adenosine, and Alcohol Dependence. Alcohol Clin Exp Res. 2014; 38(7): 1822-1825. doi:10.1111/acer.12493.

${ }^{14}$ Marczinski C.A., Fillmore M.T., Henges A.L. et al. Effects of energy drinks mixed with alcohol on information processing, motor coordination and subjective reports of intoxication. Exp Clin Psychopharmacol. 2012; 20(2): 129-138. doi:10.1037/a0026136.

${ }^{15}$ Marczinski C.A., Fillmore M.T., Henges A.L. et al. Mixing an Energy Drink with an Alcoholic Beverage Increases Motivation for More Alcohol in College Students. Alcohol Clin Exp Res. 2013; 37(2): 276-283. doi:10.1111/j.15300277.2012.01868.x.

${ }^{16}$ Marczinski C.A., Fillmore M.T., Stamates A.L. et al. The Desire to Drink Alcohol is Enhanced with High Caffeine Energy Drink Mixers. Alcohol Clin Exp Res. 2016; 40(9): 1982-1990. doi:10.1111/acer.13152.

17 Schöffl I., Kothmann J.F., Schöffl V., et al. "Vodka Energy": Too Much for the Adolescent Nephron? Pediatrics. 2011; 128 (1): e227-31. doi: 10.1542/peds.2010-2677.

18 Tomcsányi J., Jávor K. Nagy mennyiségű energiaital okozta jelentős QT-megnyúlás. Orv. Hetil., 2015; 156(43): 17581760. DOI: 10.1556/650.2015.30275

${ }^{19}$ Hammond D., Reid J.L., Zukowski S. Adverse effects of caffeinated energy drinks among youth and young adults in Canada: a Web-based survey. CMAJ Open 2018; 6 (1) E19-E25. doi: 10.9778/cmajo.20160154

${ }^{20}$ Országos Gyógyszerészeti és Élelmezés-egyészségügyi Intézet. Szilveszterkor is óvatosan az energiaitalokkal! https://www.ogyei.gov.hu/szilveszterkor_is_ovatosan_az_energiaitalokkal/ (Elérve: 2018.03.02.)

${ }^{21}$ Cseh J. Az energiaitalok szakmai megítélése határon túl. Magyar Élelmiszer-biztonsági Hivatal. https://www.antsz.hu/data/cms25815/energiaital_konf_CsJ_Energiaitalok_szakmai_megit_20100422.pdf (Elérve: 2018.09.06.)
} 
${ }^{22}$ Lege Artis Medicinae. Az energiaitalok alkoholfüggőséget okozhatnak. http://www.elitmed.hu/kiadvanyaink/ideggyogyaszati_szemle/rakszures_egyszeruen_7956/kaveval_a_cukorbetegseg_ellen_de_hogyan_6948/www.sciencedaily.com\%3Cbr\%20/az_energiaitalok_alkoholfuggoseget_okozhatnak_6462/ (Elérve:2018.03.23.)

${ }^{23}$ 2011. évi CIII. törvény a népegészségügyi termékadóról https://net.jogtar.hu/jogszabaly?docid=A1100103.TV (Elérve: 2018.03.20.)

24 Oteri A., Salvo F., Caputi P.A. et al. Intake of Energy Drinks in Association With Alcoholic Beverages in a Cohort of Students of the School of Medicine of the University of Messina. Alcohol Clin Exp Res. 2007;31(10):1677-80. DOI:10.1111/j.1530-0277.2007.00464.x

${ }^{25}$ Ballistreri M.C., Corradi-Webster C.M. Consumption of energy drinks among physical education students. Rev Lat Am Enfermagem. 2008; Spec No 16:558-64. 